\title{
Nupcie facte sunt
}

\section{Et transreformatorisk, kontekstualiserende studie af tre prædikener til anden søndag efter helligtrekonger ${ }^{1}$}

\author{
Cand.theol. \\ Jonas Kjøller-Rasmussen, Københavns Universitet
}

\begin{abstract}
The article provides a comparative study of sermons on the wedding at Cana (Second Sunday after Epiphany) from three Danish sermon collections by Peter Madsen (d. c. 1486), Christiern Pedersen (d. 1554), and Hans Tausen (d. 1561). The study draws upon methodological developments within the field of sermon studies to show the importance of a contextualizing, trans-reformation perspective: contextualizing, by referring to the context of the sermon collection in the study of the singular sermon and taking into account its purpose and compilation; trans-reformation, by referring to a selection of material from before and after the reformation in order to better understand the reception of tradition through its rejection, adaptation, and continuation. On this basis, the article argues that before and after the reformation there was general agreement in the exegesis of the pericope, but great difference in how the text was used - a difference that may partly be explained by a contextualization of the sermon.
\end{abstract}

Keywords: Peter Madsen - Christiern Pedersen - Hans Tausen - sermon - postil - preaching - trans-reformation - marriage

\section{Indledning}

I løbet af fem årtier er pradikenstudier vokset og modnet som selvstændig disciplin. Det er en disciplin, der er præget af tværfaglige metoder og materialevalg, og inden for hvilken der vedvarende stilles kritiske spørgsmål for at præcisere og udvide feltet. ${ }^{2}$ Senest har Anne T. Thayer præsenteret et overblik over den tiltagende dybde og bredde

1. Den foreliggende artikel er resultatet af det videre arbejde med udvalgte tematikker fra mit speciale, Jonas Kjøller-Rasmussen, Predikenen i Danmark 1450-1550. En komparativ analyse af Peter Madsens, Christiern Pedersens og Hans Tausens predikensamlinger (København: upubliceret speciale 2017). Jeg skylder Anna Vind stor tak for vejledning og konstruktiv kritik.

2. John W. O'Malley, S.J. "Introduction: Medieval Preaching", De Ore Domini. Preacher and Word in the Middle Ages (Kalamazoo, MI: Medieval Institute Publications 1989), 1-11; Phyllis B. Roberts, "Sermon Studies Scholarship: The Last Thirty-Five Years", Medieval Sermon Studies 43 (1999), 9-18. 
i feltet, hvor der, kombineret med en stigende tilgængeliggørelse af flere tekster, fortsat arbejdes på at inddrage flere metoder og discipliner, samtidig med at den grundige tekstlæsning ikke forsømmes. ${ }^{3}$ Det foreliggende studie ser sig i forlængelse af dette projekt og ønsker at præsentere et udsnit af dansk prædikenhistorie særligt belyst af to forhold.

Det første forhold er en indplacering af en given prædiken i sin rette kontekst som en nødvendig forudsætning for at forstå den. Kontekst forstås her både litterært og historisk udtrykt i den konkrete prædikensamling. Den enkelte prædiken ses da på samme tid som en selvstændig tekst og en del af en større, sammenhængende tekst, prædikensamlingen, som selv er et historisk levn og bør behandles som sådan. Derfor vil en gennemarbejdet forståelse af samlingens særegne karakter, formål og sammensætning være afgørende for læsningen af den enkelte prædiken. Dette står ikke i modsætning til synkrone, dogmehistoriske studier, men den kontekstualiserende læsning er et nødvendigt supplement. ${ }^{4}$

Det andet forhold er en mere systematisk opbrydning af klassiske periodiseringer. Periodiseringer er et nødvendigt redskab, når historikeren skal ordne fortidens levn, men periodisering har den uheldige bivirkning, at den inviterer til at tænke historien i blokke, fx middelalder og tidlig moderne periode med reformationen som grænsemarkør. Der er naturligvis intet nyt i at opbløde periodiseringens grænser, men der søges et mere systematisk fokus på periodiseringens begrænsninger. ${ }^{5}$ Studiet er således i sin essens transreformatorisk.

Artiklens formål er at demonstrere frugten af disse metodiske greb ved at gennemføre et studie af prædikener fra tre prædikensamlinger fra perioden før og efter den danske reformation. Det drejer sig om et teologisk blandingshåndskrift af Peter Madsen, ${ }^{6}$ Christiern Pedersens

3. Anne T. Thayer, "Medieval Sermon Studies Since The Sermon: A Deepening and Broadening Field", Medieval Sermon Studies 58 (2014), 10-27 (10-12).

4. Se fx Anne Riising, Danmarks middelalderlige prediken (København: G.E.C. Gads Forlag 1969), der præsenterer en syntese af kristendomsforståelsen i Danmark i middelalderen på basis af prædikenmaterialet. Det er et uvurderligt standardværk inden for feltet, men rummer dog visse begrænsninger, som Riising selv bemærker $\mathrm{i}$ indledningen: "Som følge af mit primære sigte har jeg foretrukket at fremlægge en analyse af hele prædikenmaterialet under ét. Det indebærer den uundgåelige ulempe, at den enkelte samlings særpræg ikke kan træde klart frem, og da prædikenerne dækker en periode på over 200 år, fra c. 1300 til 1500, er det principielt betænkeligt at behandle hele denne omvæltningsperiode som en enhed", ibid., 12. 5. Se også Berndt Hamm, "Abshied vom Epochendenken in der Reformationsforschung: Ein Plädoyer”, Zeitschrift für Historische Forschung 39, 3 (2012), 373-411. 6. Peter Madsen, Liber Petri Mathie curati ecclesie sancti Petri Ripis. The Book of Peder Madsen at St. Peter's Church in Ribe. 1454-1483, red. Anne Riising (Copenhagen u.å). Jeg har her benyttet mig af Riisings transskription, der er udgivet 
Jartegnspostil og vinterdelen af Hans Tausens postil. ${ }^{8}$ De udvalgte prædikener er fra anden søndag efter helligtrekonger, hvor prædiketeksten er brylluppet i Kana (Joh 2,1-11). Den søndag har historisk været associeret med undervisning om ægteskabet, og dermed gives også på samme tid et studie af forståelsen af ægteskabet belyst af det danske prædikenmateriale. ${ }^{9}$ På baggrund af dette typologiske studie af ægteskabet demonstreres de frugtbare virkninger af et kontekstualiserende, transreformatorisk metodisk greb.

\section{Peter Madsen}

Peter Madsens blandingshåndskrift vil være ukendt for de fleste og kræver en mere fyldig introduktion. Om forfatteren Petrus Mathie vides ikke meget. Af håndskriftet selv fremgår det, at han var sognepræst ved Sankt Peders Kirke i Ribe i den sidste halvdel af det 15. århundrede ${ }^{10}$ og ved angivelse af enkelte årstal for kopiering af visse værker, 1454-1483, formodes det, at han døde mellem det sidst anførte årstal og før 1486, hvor Sankt Peders Kirke blev annekteret af Ribe domkapitel; sådanne anneksioner hang sammen med, at et embede stod tomt. ${ }^{11}$ Håndskriftet rummer 348 folier af forskelligartet materiale. Den største del består af hjælpemidler for prædikanten, heriblandt helgenlegender, samlinger af opbyggelige anekdoter (exempla), opbyggelige skrifter, bønner og prædikener. ${ }^{12}$ Det sammenlagte materiale er ikke fyldigt nok til at dække et helt kirkeår, og prædikenerne dækker både over søn- og festdage, så håndskriftet kan hverken

elektronisk hos Syddansk Universitet. Den er baseret på Det Kongelige Biblioteks eksemplar [Miscellanea theologica:] Legenda sanctorum aliaque huiumodi res (Opstilling: Ny Kongelig Samling 123,4 ${ }^{\circ}$ og er beskrevet af Ellen Jørgensen i Catalogus codicum latinorum medii avi Bibliotheca Regia Hafniensis (Hafniensis: Gyldendalianis 1926), 163.

7. Christiern Pedersen, Alle Epistler oc Euangelia som lesiss alle Søndage om aared. sammeledis Jule dag Paaske dagh. Pingetz dag. meth deriss udtydning oc glose oc eth Jertegen till huer Dag med flere artickle som alle menniske nyttelige ere (Paris: Josse Badius Ascensius 1515).

8. Hans Tausen, Winterdelen aff Postillen berid af M. Hanss Tausen / Predickere $\ddot{y}$ Kjøbenhaffn (Magdeburg: Hanss Walther 1539).

9. John M. Frymire, The Primacy of the Postils: Catholics, Protestants, and the Dissemination of Ideas in Early Modern Germany (Leiden: Brill, 2009), 11.

10. Anne Riising, "Introduction", Liber Petri Mathie Curati Ecclesie Sancti Petri Ripis, red. Anne Riising (Copenhagen u.å.), 20-28 (20).

11. J. F. Kinch, Ribe bys historie. 1. Indtil reformationen (Århus: Universitetsforlaget i Århus 1985), 360-361.

12. Se Jørgensen (1926), 163-165 og Madsen (u.å.), 2-19 for en oversigt. 
betragtes som en sermones de tempore eller de sanctis. ${ }^{13}$ Til gengæld er der ofte flere forskellige prædikener til hver dag. Et muligt ordningsprincip for materialet kan dog tilnærmes: I synodalstatutterne for Slesvig domkapitel fra 1352 finder man en liste, der fastsætter en række festdage, hvor der bør prædikes. ${ }^{14}$ Denne liste har meget tilfælles med håndskriftets udvalg, og hvis lignende krav var blevet stillet i Ribe stift, ville Peter Madsen med dette i hånden have kunnet leve op til de grundlæggende forventninger til en sognepræsts prædikenvirksomhed. Peter Madsens arbejde med sin bog har haft et praktisk og pragmatisk sigte, hvor han i en periode på omtrent 30 år kopierede prædikener og andet efter behov for at kunne tilfredsstille gejstlighedens forventninger og tilbyde tilhørerne passende variation. ${ }^{15}$

Man finder to prædikener om ægteskab hos Peter Madsen. Den ene henter sit thema fra Joh 2,1 og skal holdes anden søndag efter helligtrekonger, mens den anden henter sit thema fra Hebr 13,4 og har blot overskriften "Anden prædiken om et bryllup". ${ }^{16}$ De er dog begge kopieret fra den samme prædiken hos den polske dominikaner Peregrinus Polonus, som var en primær inspirationskilde for Peter Madsen, og der er store indholdsmæssige overlap. ${ }^{17}$ Her tages udgangspunkt i prædikenen over Joh 2,1, mens der suppleres med henvisninger til "Anden prædiken om et bryllup".

Peter Madsen indleder sin prædiken i stil med den meget udbredte prædikentype, sermo modernus, der er kendetegnet ved at benytte et enkelt bibelvers som sit thema og strukturere prædikenen gennem et sæt af inddelinger og underinddelinger af dette thema. Først præsenteres denne prædikens thema: Nupcie facte sunt in Cana. Dernæst følger inddelingen, divisio thematis, hvor Peter Madsen spiller på den flerfoldige betydning af matrimonium: For det første betegnes det kødelige ægteskab mellem mand og kvinde. For det andet det åndelige ægteskab mellem Gud og sjælen, som fx finder sted i dåben, og for det tredje det evige ægteskab, som vil finde sted i fædrelandet, altså i den

13. Sermones de tempore er en genrebetegnelse for en prædikensamling, der dækker kirkeårets søndage og de største festdage, mens sermones de sanctis indeholder prædikener over mindre festdage og helgendage.

14. Riising (1969), 18: "Jul, Hellig tre Konger, påske, pinse, Kristi himmelfart, Kristi legemsfest, apostlene Peter og Paulus' dag, Allehelgen, kirkens indvielsesdag, Marias 4 fester: bebudelse, renselse, fødsel og himmelfart, samt askeonsdag, skærtorsdag, de to fester for korset, dagen for apostlen Peters fængsling samt på relikviefesten."

15. Der er ofte 2-4 forskellige prædikener til søn- og festdage, mens der er hele fem juleprædikener og seks til Mariæ bebudelsesdag.

16. Dominica $2^{\mathrm{a}}$ p. Ep., Madsen (u.å.), 224 og In nupciis sermo $2^{\text {us }}$, ibid., 625.

17. Peregrini de Opole, Sermones de Tempore et de Sanctis, red. Richardus Tatarzyński (Warszawa: Instytut Tomistyczny 1997), 48-52; Riising (u.å.), 21. 
himmelske salighed..$^{18}$ Herefter følger en underinddeling, subdivisio, af det første punkt, mens de to andre ikke behandles yderligere. Med udgangspunkt i en udbredt topos beskrives ægteskabets fire værdigheder i sammenligning mellem ægteskabets stand og religiøse ordener. ${ }^{19}$

De første tre værdigheder uddyber, hvordan dette forholder sig, og hvordan ægteskabet egentligt er en bedre orden end andre religiøse ordener, ${ }^{20}$ mens den fjerde er med til at underbygge det. For det første kaldes æegteskabet en religio, ${ }^{21}$ men mens andre religiones er stiftet af mennesker, er ægteskabet stiftet af Gud alene, og man har endda Kristus selv som abbed. For det andet og tredje blev ægteskabet stiftet $\mathrm{i}$ en lykkeligere tid og et lykkeligere sted, nemlig før syndefaldet. Denne prælapsarisk funderede ordning gør det muligt at leve i ægteskabet uden synd og nå til det højere Paradis: Himlen. ${ }^{22}$ For det fjerde viste Gud ægteskabet en stor ære ved at besøge brylluppet og smykke det med et tegn. Disse fire topoi er, blandt andre, meget almindelige i middelalderlige prædikener over brylluppet i Kana, og Peter Madsen repræsenter en klassisk formulering af middelalderens forståelse af ægteskabet (d'Avray 2005, 68-70). Til sidst bringes en række formaninger i direkte tiltale, der beskriver, hvordan man lever ret og tilbørligt i ægteskabet. Som overskrift står formaningen om at bevare den gensidige kærlighed, men dets konkretiseringer rettes mod manden, der skal elske sin hustru mere end nogen anden kvinde, uanset hvor smuk, ædel eller rig en anden kvinde måtte være. Han skal elske

18. Madsen (u.å.), 224: "Primum matrimonium est carnale inter virum et mulierem, et ad illud matrimonium pertinent nupcie, de quibus agitur. $2^{\mathrm{m}}$ est spirituale et hoc est inter Deum et animam, utputa in baptismo. $3^{\mathrm{m}}$ matrimonium est eternale et hoc erit in patria".

19. N. Bériou \& D. L. d'Avray, "Henry of Provins, O. P.'s Comparison of The Dominican and Franciscan Orders with the "Order" of Matrimony", Modern Questions about Medieval Sermons. Essays on Marriage, Death, History and Sanctity, red. Nicole Bériou m.fl. (Spoleto: Centro italiano di studi sull'alto medioevo 1994), 71-75.

20. At indgå i ægteskabet er også en mere alvorlig sag end andre ordener, for ægteskabet har ikke et års prøvetid, og mens paven kan tillade, at man indtræder fra én orden til en anden, kan end ikke paven bryde et lovligt indgået og fuldbyrdet ægteskab, Madsen (u.å.), 625. For en uddybende diskussion af betydning af fuldbyrdelsen i ægteskabet se David d'Avray, Medieval Marriage: Symbolism and Society (Oxford: Oxford University Press 2005), 168-199.

21. I de to prædikener bruges religio og ordo synonymt, Madsen (u.å.), 625 .

22. Denne insisteren var sandsynligvis rettet mod katharerne og deres negative syn på ægteskab og sex, som bl.a. indebar, at ægteskabet kunne betragtes som rent hor, purum meretricium, og at det eneste sande ægteskab var mellem sjælen og Gud, d'Avray (2005), 65-67; Mark Gregory Pegg, The Corruption of Angels. The Great Inquisition of 1245-1246 (Princeton: Princeton University Press), 55. 
hende så ivrigt, at han ikke taler et ondt ord til hende eller slår hende, ${ }^{23}$ og han skal elske hende som sig selv ved at sørge for klæder, føde o.a. Sammenlignet med dets forlæg hos Peregrinus Polonus er Peter Madsens prædikener fragmentariske, som hans divisio thematis også afslører. Ikke blot udelades subdivisio to og tre, men blandt de mere konkrete formaninger behandler Peter Madsen kun dilectio/charitas og springer fidelitas, temperantia, adiutorium og honesta educatio filiorum over. Det kan umiddelbart synes som en kopieringsfejl, og virke noget sløset. Især fordi divisio thematis ikke justeres til prædikenens faktiske indhold, så det bliver tydeligt, at der er noget, der mangler. Sat ind i blandingshåndskriftets større kontekst vil det dog vise sig, at der ikke er tale om tilfældigt sløseri, men at det er en bevidst strategi. Lige fra det overordnede udvalg til behandlingen af dets indhold er Peter Madsen pragmatisk orienteret. Han kopierer det materiale, som i Slesvig ville have været nok til at leve op til de grundlæggende forventninger, men viser samtidig interesse for at levere variation i indholdet. Til de enkelte prædikener tager han det, han kan bruge i den konkrete situation. Det er ikke sjældent, at han præsenterer en divisio thematis, der indeholder flere elementer end dem, som han derefter gennemgår. ${ }^{24}$

Denne eklektiske tilgang afspejler en korrespondance mellem samlingens indhold og prædikenen til anden søndag efter helligtrekonger. Samlingen kendetegnes ikke af vidtløftige teologiske diskussioner, men præsenterer i sin simple form et sæt af konkretiserede muligheder for, at synderen, der har fortørnet Gud, kan afvende Guds vrede fra sig. På den ene side er der mulighed for at påberåbe sig kraften i Kristi blod og Marias og helgenernes forbøn som levende og sikre midler til at formilde Gud. På den anden side tilbydes en fortrøstningsvej gennem ritualet, skriftemålet, bestående af den i samlingen ofte forekommende treklang af contritio, confessio og satisfactio. Over for en menighed af lægfolk koncentrerer Peter Madsen sig om det konkrete jordiske ægteskab, idet han først forsikrer dem om det legitime i deres stand, at også ægtefolk kan nå til himlen, og han supplerer det med konkret vejledning om, hvordan de skal leve retteligt i denne stand.

23. Peter Madsen tilføjer her i "Anden prædiken om et bryllup", at mange mænd drikker sig fulde på kroen og udsættes for fornærmelse i ord eller gerning, men får først forløsning, når de kommer hjem og lader det gå ud over hustruen, Madsen (u.å.), 626. Selvom det ikke kan afvises, at Peter Madsen taler ind i en kendt lokal situation, må man huske på, at den direkte formulering i timeo quod er hentet fra Peregrinus Polonus (1997), 49.

24. Se fx In Domenica prima adventus, ibid., 627, De exaltacione sancte crucis, ibid., 269 og De sancto Nicolao, ibid., 215. 


\section{Christiern Pedersen}

Mere kendt vil Christiern Pedersens Jærtegnspostil være, dels gennem enkelte specialiserede studier, ${ }^{25}$ og dels gennem en større interesse for Christiern Pedersen som person. ${ }^{26}$ Titlen "Jærtegnspostil" var en senere betegnelse og blev tildelt postillen på grund af dens mange jærtegn, exempla. Postillen blev trykt i 1515 på 204 folier og kan siges at høre til genren sermones de tempore. Selvom reformationens indtræden nok har sat en grænse for postillens udbredelse, så er der noget, der tyder på, at den vandt en vis popularitet. Den fik sit andet optryk allerede i 1518, og fragmenter i den Arnamagnæanske Samling angiver, at $\mathrm{i}$ hvert fald en del blev oversat til islandsk (Riising 1969, 63). Desuden findes senere henvisninger til den i både Sverige ${ }^{27}$ og i Norge. ${ }^{28}$

Postillen er tilrettelagt efter et fast mønster, der dog fortrinsvist følges i postillens første del. Først bringes epistelteksten efterfulgt af en udtydning - en genfortællende forklaring. Dernæst evangelielæsningen, ligeledes efterfulgt af en udtydning og prædikenmateriale af forskellig art (ibid., 482-490; Jensen 1991, i-xxvii). Til sidst bringes et eller flere jærtegn, der passer til dagen. Det har givetvis også været intentionen at indlemme en decideret prædiken til hver dag, men samlingens blot seks prædikener skal findes mellem første søndag i advent og helligtrekongers søndag. Ligeledes er episteludtydningerne forbeholdt adventstiden, septuagesima og fastelavnssøndag (Brandt $1882,74)$. Postillen er udgivet på dansk, og der ligger et betydeligt oversættelsesarbejde af bibelske tekster og prædikenmateriale til grund for den. En proces, som har ligget i naturlig forlængelse af Christiern Pedersens formål med postillen, der, udover at have været en nyttig bog for en præst, også var tiltænkt lægfolket til opbyggelse. Han skriver i forordet:

25. Pil Dahlerup, Sanselig senmiddelalder. Litterere perspektiver på danske tekster 1482-1523 (Århus: Århus Universitetsforlag 2010), 215-232; Johan R. M. Jensen, Den rette vej til himmeriges rige. Studier $i$ Christiern Pedersens bevidsthedsmassige udvikling (København: upubliceret speciale 1991).

26. Se bl.a. biografierne C. J. Brandt, Om Lunde-kanikken Christiern Pedersen og hans skrifter (Kjøbenhavn: G. E. C. Gad 1882) og Jens Anker Jørgensen, Humanisten Christiern Pedersen: En prosentation (København: A. C. Reitzel 2007).

27. Biskop Hans Brask anbefalede i 1525, at man brugte Jærtegnspostillen som alterbog i stedet for at lave en ny oversættelse af Det Nye Testamente, da postillen indeholder danske oversættelser af alle kirkeårets perikoper, Brandt (1882), 79-80.

28. Hans Jakob Wille, Beskrivelse over Sillejords Prastegield i Øvre-Tellemarken $i$ Norge, tilligemed et geografisk Chart over samme (Kiøbenhavn: Gyldendals Forlag 1746), 48. 


\begin{abstract}
Alle enfoldige $\mathrm{Da}(\mathrm{n})$ ske folk so(m) icke forstaa latine til nøtte oc salighed Ere alle Epistler och Ewa(n)gelia som læsiss alle søndage udsette paa danske met deriss udtydninger oc i Jerteghen til hwert aff dem At de som icke latine forstaa Mue nw selffue læse paa danske hworlediss de rettelige leffue skwlle effter gwds budord som stonde i dem ... Thii er det nytteligt och vel tilbørligt ath de udsettis paa reth danske faar endfoldige ligfolk skyld som icke forstaa latine Oc sacte ey helder fo(n)ge tit predicken (Pedersen 1515, 1v).
\end{abstract}

Om hans beskrivelse af prædikensituationen i Danmark her er helt præcis, er nok tvivlsomt, da det var helt almindeligt, at man prædikede på folkesproget, også selvom de fleste prædikensamlinger er overleveret på latin. ${ }^{29}$

Christiern Pedersens prædiken over brylluppet i Kana har titlen "Den søndag nest effter tyuende dag Jule" og indeholder først en oversættelse af epistel- og evangelieteksten (ibid., fol. 54r-60r). Selve prædikenmaterialet kan inddeles i tre dele og afsluttes med et jærtegn. De tre dele består i en udtydning af teksten disponeret i tre artikler, en tredobbelt udlægning af de seks stenkar og en traktat om ægteskabet. Udlægningen af stenkarrene følger sensus spiritualis, og de seks stenkar betegner således seks grunde til, at Jesus blev menneske, seks sorger, som apostlene havde på grund af Jesus pine og død, og seks sorger, som ethvert menneske bør have på grund af sine synder. Da vores tematiske ledetråd er ægteskabet og brylluppet i Kana, skal stenkarrene ikke optage os yderligere her. Udtydningen er en ligefrem tekstgennemgang, som består af oversatte tekstbidder fra en postil af den såkaldte "Guillermus Parisiensis". ${ }^{30}$ Guillermus er dog blot den pseudonyme redaktør, og hovedparten af indholdet er baseret på dominikaneren Johann Herolts Sermones Discipuli, der var enormt populær i det 15 . årh. ${ }^{31}$

Udtydningen er disponeret efter tre artikler, hvis inddeling er Christiern Pedersens egen tilføjelse, og har karakter af en divisio thematis, selvom de enkelte elementer er hentet fra forskellige steder i teksten: 1) Ægteskabet prises, nupcie facte sunt. 2) Det store jærtegn Jesus gjorde, deficiente vino. 3) Disciplenes tro stadfrstedes, hoc inicium signorum. Efter at have redegjort for brylluppets historiske placering i Jesu liv påbegyndes udtydningen. At Jesus var indbudt til brylluppet viser,

29. Per Ingesman \& Nils Arne Pedersen, Kirkens historie. Bind 1 (København: Hans Reitzel 2012), 576.

30. Guillermus Parisiensis, Postilla Guillermi super epistolas et evangelia de tempore et de sanctis et pro defunctis (Basel 1506), fol. 14r-15r.

31. Ian D. K. Siggins, A Harvest of Medieval Preaching. The Sermon Books of Johann Herolt, OP (Discipulus) (Bloomington, IN: Xlibris Corporation 2009), 302-304. 
at det skal sættes højt. For hvis det var en synd at leve i ægteskab, ville Jesus og hans disciple ikke være mødt op til brylluppet. Desuden blev Jesus indbudt, ikke fordi han var en mægtig herre, men fordi han var en slægtning til brudeparret. Deraf kan man lære, at man skal tage sig af sine fattige slægtninge, da både Jesus og brudeparret var fattige. Selvom det indrømmes, at Jesu svar til Maria var hårdt, så fremhæves deres nære relation. Maria turde spørge Jesus om dette jærtegn i fuld tillid til, at han også ville gøre det, og hun bad ham aldrig om noget, uden at han gjorde det. Jærtegnet bevirkede, at disciplene blev stadfæstet i deres tro, fordi Jesus ikke tidligere havde gjort noget lignende, men dette var blot begyndelsen på de undergerninger, Jesus gjorde på jorden. I en tilføjelse til Guillermus inddrager Christiern Pedersen en beretning om brudeparrets identitet. Her trækker han på en tradition om, at brudgommen var Johannes Evangelisten, og bruden en af de jomfruer, som fulgte Jomfru Maria - i enkelte beretninger ekspliciteret som Maria Magdalene. ${ }^{32}$ Christiern Pedersen beskriver, hvordan Johannes ved denne lejlighed, altså ved sit eget bryllup, blev kaldet til at følge Jesus i tjeneste for Gud i cølibat. Det gjorde Jesus for at vise, at når et ægteskab ikke er fuldbyrdet, og når begge ønsker at leve som jomfruer i tjeneste for Gud, da er det tilladt at bryde et ægteskab op. Sammen med incest var manglende fuldbyrdelse en af de få legitime årsager til at få annulleret et ægteskab i middelalderen, omend grænsedragninger i praktiske sager kunne variere betydeligt (d'Avray 2005, passim).

Traktaten om ægteskabet er oversat fra Herolt. ${ }^{33}$ Christiern Pedersen springer de indledende bemærkninger fra Herolt over og beskriver direkte, hvordan Gud har æret ægteskabet. Det første afsnit fremhæver ægteskabets ligeværdige status med monastiske ordener - ja, det er endda "den ypperste or=den og regeel som til er" (Pedersen 1515, fol. 57v). Ift. Peter Madsen medtager Christiern Pedersen også, at Gud ærede ægteskabet ved at lade sig føde af Jomfru Maria, som var i et ægteskab, og ved at lade ægteskabet indstifte som et af kirkens syv sakramenter. Fordi Gud har hædret ægteskabet, bør man også give agt på det, hvilket beskrives i fem punkter. ${ }^{34}$ For det første bør man have kærlighed til hinanden, som skal overgå kærligheden til alt andet her i verden. Symbolet på den kærlighed er en guldring, der ved

32. Annette Volfing, John the Evangelist and Medieval German Writing: Imitating the Inimitable (Oxford: Oxford University Press 2001), 29-31.

33. Johann Herolt, Sermones Discipuli de tempore et de sanctis (London 1510), fol. 34r-36r.

34. Christiern Pedersen angiver at ville udfolde syv punkter, men har sprunget to af Herolts punkter over: Om mådehold og ærlighed i ægteskabet og om børneopdragelse. 
sit ædle metal og runde form, der symboliserer evigheden, er mere værd end alt timeligt gods. Denne kærlighed skal komme til udtryk, ved, at man ikke taler ondt til hinanden, men tager sig af hinanden, og ved at kvinden viser manden ære. For det andet bør man leve i fred med hinanden, men skal tåle de lidelser, man kommer ud for, hvis man lever i ufred. Lidelse i ægteskabet får også meritorisk karakter og fraregnes pinen i skærsilden, når man lever med en genstridig kvinde eller en voldelig mand. ${ }^{35}$ For det tredje advares mod utugt i æagteskabet. Det begrundes dels moralsk gennem ægteskabets sakramentale karakter, hvor hor sammenlignes med tyveri og mord, og dels gennem skræk for den pine, der venter den utugtige. For det fjerde skal de hjælpe hinanden, $\mathrm{fx}$ ved børneopdragelse, som også får meritorisk karakter, hvis børnene opdrages fromt. For det femte skal de indvillige $\mathrm{i}$ at opfylde seksuelle behov, når disse opstår. Dog kun så længe formålet er at skabe afkom, og at man lever afholdende på de tider om året, der er indrettet dertil. ${ }^{36}$

Til sidst gives et jærtegn om et nygift par, hvor hustruen først havde lovet sig som Kristi brud. Hun var derfor meget ulykkelig, da de på bryllupsnatten skulle fuldbyrde ægteskabet. På baggrund af hendes klage og beskrivelse af belønningen for et jomfrueligt liv besluttede manden, at han ville leve som jomfru sammen med hende resten af deres liv. Efter et langt liv døde først hustruen og dernæst manden, og de blev begravet på hver deres side af kirken. Dagen efter mandens begravelse kunne folket se, at deres grave havde rykket sig, så de nu lå ved siden af hinanden. Heraf kunne man se, at ægtefolks sjæle ligefuldt vil være sammen i himlen, som de legemligt var sammen på jorden, også selvom de havde levet seksuelt afholdende.

Også Christiern Pedersens prædiken giver et fragmentarisk indtryk, men på en anden måde end Peter Madsens prædiken gjorde det. Det er fragmentarisk, ikke blot ved at hvert afsnit kun delvist indlemmes i prædikenmaterialet gennem oversættelse fra dets forlæg, men også ved at prædikenmaterialet sammenstykkes fra forskellige kilder. Dertil kommer Christiern Pedersens egne tilføjelser, der sammen med oversættelsen transformerer materialet. Ægteskabets værdi bekræftes utvetydigt gennem Jesu tilstedeværelse ved brylluppet, som hos Peter Madsen, og ægteskabet beskrives ligefrem som en bedre orden end menneskeligt indstiftede ordener. Alligevel aner man en indre konflikt i prædikenen, når det bliver klart, at der er noget andet, der er vigtigere. På trods af at Jesus viste ægteskabet ære ved at deltage

35. Inden Christiern Pedersen går til næste punkt, udelader han her et længere afsnit om, hvorvidt og hvornår en mand må slå sin hustru, Jensen (1991), viii.

36. En lignende liste over, hvornår man skal være seksuelt afholdende, findes også i Peter Madsens In nupciis sermo 2us, Madsen (u.å.), 626. 
i brylluppet, så konkluderer Christiern Pedersen i udtydningen, at Jesus bryder ægteskabet op for at sætte dem fri til et bedre liv: En tjeneste for Gud i jomfruelighed. I tillæg til dette vælges et jærtegn fra Gregor den Stores dialoger og ikke fra Herolt, som de fleste andre jærtegn i postillen (Jensen 1991, viii), og dermed demonstrerer det fuldgyldige i et ægteskab levet i seksuel afholdenhed. I de konkrete formaninger finder man også en række betoninger, der viser, at Christiern Pedersen har et helt andet udgangspunkt end Peter Madsen.

Hele formålet med Jærtegnspostillen kommer til udtryk i et gennemgribende ønske om, at alle, både læg og lærd, må blive salige. Dette er kun muligt, idet man forstarr, hvad der er indholdet af Guds lov og vilje, så man kan leve efter det. Det er denne hensigt, der ligger bag, når Christiern Pedersen inddrager en tolkning af de seks stenkar, der er orienteret mod den enkeltes bod og bekendelse, og når han retter de konkrete formaninger mod målet om at opnå den kommende salighed ved at leve i ægteskabet. Det er bemærkelsesværdigt, at kvinden hos Christiern Pedersen får løn i himlen for hvert slag hun, lider tålmodigt, mens Peter Madsen forklarer, at den kærlighed, man skal have i æateskabet, bør komme til udtryk på en sådan måde, at manden ikke gør ondt mod kvinden hverken i ord eller handling. Måske er det her, man finder den forskel, der er på at udvælge prædikener til sin egen menighed i Ribe eller til det danske lægfolk generelt fra et intellektuelt, humanistisk miljø i Paris.

\section{Hans Tausen}

Hans Tausens postil runder kildeudvalget af, idet det transreformatoriske perspektiv kommer til sin ret. Tausen var en markant figur i den danske reformation, og derfor er det ikke overraskende, at hans værker, deriblandt postillen, før er blevet genstand for opmærksomhed. ${ }^{37}$ Postillen blev trykt i Magdeburg i 1539 og udkom i to bind på hhv. 219 og 329 folier, hvortil der i vinterdelen også blev indbundet et tillæg til påskeugen på 59 folier. En nærmere genrebestemmelse viser sig at være problematisk, for postillen ser ud til at bryde med de klassiske genrebetegnelser. Postillens hoveddel består af prædikener over eller udlægninger af epistel- og evangelielæsningerne til kirkeårets sønda-

37. Se bl.a. Knud Eyvin Bugge, red., Tro og tale. Studier over Hans Tausens Postil (København: G. E. C. Gads Forlag 1963), Rasmus H. C. Dreyer, Hans Tausen. Forskning. Historie. Teologi. Prisopgavebesvarelse: "Studier i Hans Tausens forhold til Luther” (København: upubliceret prisopgave 2010) og Lasse Rødsgaard Lauesen, Studier i Hans Tausens forhold til Luther (København: upubliceret prisopgave 2010). 
ge med tilhørende oversættelse af perikoperne. Derudover indeholder den et udvalg af dage, som normalvis ville høre hjemme i genren sermones de sanctis. ${ }^{38}$ En mulig forklaring kan findes i det tætte samspil mellem postillen og den danske kirkeordinans. Tausen var blandt de prædikanter, der var involveret i udarbejdelsen af kirkeordinansens første udkast. Det vil derfor ikke være overraskende, hvis man kan spore en relation mellem kirkeordinansen og postillen, når man erindrer, at de blev udgivet i hhv. 1537 og 1539. ${ }^{39}$ Først og fremmest kan man se det gennem det genrebrydende udvalg af søn- og festdage, som meget præcist dækker de rammer, som kirkeordinansen sætter for hvilke festdage, der skal bibeholdes efter reformationen. ${ }^{40}$ Mere vægtig er dog den liste af specifikke regulativer, hvor kirkeordinansen fastsætter rammer for, hvilke tekster og temaer der skal prædikes over på et udvalg af søn- og festdage (Ordinatio 1537, fol. 12v-14r).

Selvom der ikke er komplet sammenfald, er der et markant overlap mellem disse forordninger og Tausens postil. Især bør bemærkes, at kirkeordinansen foreskriver, at Johannes Bugenhagens passionsharmoni bør læses i påskeugen, og Hans Tausens påsketillæg indeholder netop en dansk oversættelse af Stefan Roths udgave af Bugenhagen (ibid., fol. 13v; Dreyer 2010, 311). Forordningerne afviger desuden betydeligt fra den førreformatoriske tradition og flere andre luthersk orienterede postiller. ${ }^{41}$ En stor udfordring for reformatorerne var, at sognepræsterne i det store hele blev i deres embeder efter reformationen, og postillen udfyldte et behov for at opdrage de blivende præster i den nye evangeliske tro (Lausten 2016, 175). I en kort bemærkning i kirkeordinansen gives en indrømmelse til sognepræsterne på landet, hvorved de får lov til at læse højt fra en dansk postil ved gudstjenesten, indtil de får lært at prædike selv (Ordinatio 1537, fol. 11v). ${ }^{42}$ Tausens postil er helt specifikt designet til at give sognepræsten mulighed for at leve op til kirkeordinansens krav, og postillens dedikation til Christian III viser, at også sognepræsten selv var genstand for dens oplærende funktion:

38. Det drejer sig om Mariæ renselse, Mariæ bebudelse, Kristi himmelfart, St. Hans, Mariæ besøgelse, St. Mikkels dag og Allehelgen.

39. Martin Schwartz Lausten, Reformationen i Danmark (København: Eksistensen 2016), 135-137.

40. Ordinatio Ecclesiastica Regnorum Dania et Norwegia et Duca=tuum / Sleswicensis / Holtsatice etcet. (Hafnia: Joannis Vinitoris 1537), fol. 12v.

41. Sml. Christiern Pedersens postil eller Antonius Corvinus \& Petrus Parvus, Postilla offuer de Sondagis Evangelia, som falde om alt Aarit (Roschilde: Hans Barth 1539).

42. Dette trækkes tilbage i både 1546 og 1555, Jens Chr. V. Johansen, "Preacher and Audience: Scandinavia," Preachers and People in the Reformations and Early Modern Period, red. Larissa J. Taylor (Leiden: Brill 2001), 297-325 (309). 
Er willien god / da kan man her med behielpe seg / oc begrunde her aff saa meget / att en mand kan lære seg først sielff en heel uge / oc siden om søndagen lære sine sognefolk nogen sand oc wiss grund / da om troen / nu om gode gerninger / efter som Eua(n)gelium wdi texten wdkreffuer (Tausen 1539, 8r-8v).

Postillens indhold følger en fast struktur, hvor der først er en oversættelse af epistelen fulgt af en forklarende disposition og dernæst en oversættelse af evangelieteksten fulgt af en udlæggende prædiken. Prædikenen til anden søndag efter helligtrekonger afviger en smule i episteludlægningen (ibid., fol. 100v-108v). Hans Tausen angiver her, at hver del af Rom 12 tilsyneladende "giffuer seg wel sielff klarlig nok tilkende med forstan=delige ord" (ibid., fol. 101v) og ikke har behov for yderligere udlægning. Herefter følger oversættelsen af evangelieteksten og prædikenen dertil. Kildegrundlaget for Tausens postil er et grundlæggende problem. At Luthers prædikener er en gennemgående inspiration er utvivlsomt, men mere usikkert er, hvilken udgave der har dannet grundlaget postillen. I henhold til Dreyers store forarbejde forekommer det, at både Luthers Kirkepostil og Roths udgivelse af Luthers prædikener i en række postiller er de mest sandsynlige forlæg, men det understreges samtidig, at Tausens postil som minimum må betragtes som en mere bearbejdet oversættelse med store redaktionelle friheder (Dreyer 2010, 344-346). Det gælder også for Tausens prædiken til anden søndag efter helligtrekonger, hvis man overhovedet kan tale om egentlige forlæg. Allerede Finn Fosdal bemærkede, at Luthers Kirkepostil som forlæg ikke virkede overbevisende,${ }^{43}$ og en sammenligning med Roths udgave afslører så store forskelle, at den ikke kan betragtes som et forlæg, men man kan blot identificere enkelte overlap. ${ }^{44}$ Højst kan det indledende "Summa des Euangelions", der er oversat fra Bugenhagens Postillatio, betragtes som et dispositionelt forlæg. ${ }^{45}$ På baggrund af dette vil prædikenen her blive behandlet som et selvstændigt arbejde, men der tages forbehold for, at et forlæg senere kan blive mere præcist identificeret.

43. Finn Fosdal, "Luthers kirkepostil og Hans Tausen postil," Tro og tale. Studier over Hans Tausens postil, red. Knud Eyvin Bugge (København: G.E.C. Gads Forlag, 1963), 15-126 (72).

44. Det gælder bl.a. afsnittene om brudgommens identitet, deltagelse i gilder, Jesus viser ægteskabet ære og Marias vedholdenhed, men rækkefølgen er ikke den samme. Samtidig forsvinder hos Tausen det store afsnit om tro, kærlighed og kors i ægteskabet, og han tilføjer et betydeligt afsnit om jærtegn, jf. WA 21,56-65.

45. WA 21, 57; Johannes Bugenhagen, Postillatio Ioan. Bvgenhagii Pomerani in Euangelia, usui temporu $(m)$ \& Sanctoru $(m)$ totius anni seruientia, ad preces Georgii Spalatini scripta (Basel, 1524), B 4v-B 5r. 
Tausen har disponeret sin prædiken over fire hovedafsnit af varierende længde. Det første (og længste) afsnit har ægteskab og bryllup som sit fokusområde, mens de to midterste afsnit afdækker forskellige aspekter af Jesu og Marias interaktion. Det sidste afsnit handler om betydningen af forvandlingsmiraklet og om jærtegn i almindelighed. Inden Tausen behandler ægteskabets stand, bringer han et forsvar for deltagelse i gilder. Jesus deltog jo selv i festlige sammenkomster og viste dermed, at det ikke er nogen synd at deltage i gilder, Collatz, hvor mad og drikke indtages i mere end dagligdags mængde. Dette er vendt mod gendøberne, som, ifølge Tausen, mener, at det er en dødssynd at indtage det mindste, efter at sulten eller tørsten er slukket. Dog skal det ikke ses som en anledning til fråseri, men man skal søge det gode kristne selskab, der kan være til opbyggelse og til gavn for "dennom som arbeyde for oss wdi Guds ord / fremmede og husswilde / encker oc faderløse / med alle andre wedtørfftige / som wÿ haffue befaling" (Tausen 1539, fol. 104r). Dernæst bekræfter Tausen de to foregående forfattere i, at Jesus viser ægteskabet en stor ære ved at være tilstede ved brylluppet, men han vender det polemisk mod agteskabsforagterne, der pålægger gejstligheden et krav om cølibat. Det er imod dette krav, at Jesus sammen med sine disciple og sin mor pryder ægteskabet med sin tilstedeværelse og smykker ægteskabet med sit første jærtegn.

Derefter følger en ny variant af den nu nok så velkendte liste over ægteskabets værdigheder. Gud stiftede ægteskabet i Paradis, mens mennesket var i uskyldighedens stand og under Guds nåde. Både patriarkerne og flere andre personer fra Det Gamle Testamente levede i ægteskabet, og selveste Guds søn lod sig undfange og føde inden for ægteskabets stand. Herefter forholder Tausen sig til spørgsmålet om brudgommens identitet og afviser, at det skulle være Johannes Evangelisten, med henvisning til Johannes' kaldsberetning i Matt 4 og en fastholdelse af, at Jesus ikke ønskede at skille det, som Gud havde sammenføjet (i ægteskabet). Den slags beretninger bør ikke give nogen den forestilling, at det er bedre at leve ugift. Det må gå forud for at vælge den ugifte stand, at man har prøvet sig selv, om man kan leve et rent og helligt liv og acceptere den hårde dom, hvis man fejler. Hvis man ikke kan det, må man gifte sig, for ægteskabet er det gode værn mod utugt. Afsnittet sluttes af med en trøsterig opmuntring om, at Gud vil velsigne gudfrygtige ægtepar, så de ikke skal mangle til dagligt hushold, selvom de er fattige.

I afsnittet med overskriftet "Maria sagde / de haffue icke wÿn", vender Tausen sig først mod en bemærkning fra Johannes Chrysostomus om, at Maria skulle have sagt dette af hovmod for at skaffe sig selv ære ved sin søns mirakel. Tausen siger derimod, at hun gjorde det i 
en god hensigt af hensyn til ægteparret, som ville være blevet gjort til skamme, hvis gæsterne var begyndt at forlade festen så tidligt. I næste afsnit, "Hwad han siger eder for det giører", er Maria et eksempel for den bedende kristne, der med ihærdig, udholdende påtrængenhed ikke lader sig afvise, men i sand tro og tillid ikke behøver andet end at bringe sit behov til Jesus. Dermed ses, "att Maria er oss her ett leffuendes exem=pel / bode wdi troen til Gud / oc ÿ kiærlighed til hwer andre" (ibid., fol 107r). Det sidste afsnit har overskriften "Med dette sitt første jertegen bete=de Jesus sin herlighed / oc hanss disciple etc." (ibid.), og det handler om betydningen af jærtegn. De tjener - eller har tjent - til at åbenbare den skjulte guddommelighed i Jesus og understøtte hans lærdoms ord, så evangeliet kan tros og bekræftes. Prædikenen afsluttes med en advarsel mod falske jærtegn. De sande jærtegn defineres gennem deres virkning, idet de vil føre til den bekendelse, at "Jesus Christus er werdsens frelsere / oc att der er ingen Guds naade eller synds forladelse ÿ nogen ting / wden ÿ hannom alene" (ibid., fol. 108r-108v), mens falske jærtegn fører til vranglære.

Tausens prædiken er primært tekstudlæggende og følger derfor teksten snarere end en på forhånd givet disposition, selvom man kan finde enkelte hovedafsnit. Den simple, fortløbende udlægning af teksten giver indtryk af at være sammenhængende prædiken over Joh 2,1-11 i en luthersk kontekst, men på basis af det foregående bør man gøre to vigtige observationer. Den første observation handler om forholdet mellem eksegese og forkyndelse i det transreformatoriske spænd. Stillet op ved siden af hinanden viser det sig nemlig, at både Peter Madsen, Christiern Pedersen og Hans Tausen forstår perikopen på stort set samme måde. Jesus viser ægteskabet en stor ære ved sin tilstedeværelse ved brylluppet. Dette er grundkernen i deres syn på ægteskabet, og også Hans Tausen viderefører denne forståelse, der kan spores langt tilbage i middelalderen, som allerede vist. I den henseende har reformationen intet ændret på, hvordan perikopen til anden søndag efter helligtrekonger blev forstået, og grundelementet i, hvad ægteskabets værdigheder består af, er også bevaret. Det, som har ændret sig, er, hvordan denne forståelse af teksten appliceres inden for den konkrete kontekst, som forfatterne befinder sig i. For mens Peter Madsen koncentrerer sig om konkrete virkemidler og opmuntring til sin reelle menighed, hvori mange sikkert levede i ægteskab, og Christiern Pedersen på afstand søger at informere om vejen til salighed, også hvis man skulle vælge at leve i ægteskab, selvom der er en bedre vej, så griber Tausen et kardinalpunkt for reformatorerne, og med samme grundforståelse af teksten som Peter Madsen og Christiern Pedersen tordner han mod kravet om cølibat blandt gejstlige og anden kritik af ægteskabets stand. 
Den anden observation angår forholdet mellem Tausens prædiken og postillen som helhed. Med et grundlæggende kendskab til retorikken i reformationstidens skrifter er det måske ikke overraskende, at Tausens prædiken synes at have et polemisk anstrøg, jf. kritikken af gendøberne, ægteskabsforagterne, Chrysostomus, legenden om Johannes Evangelisten og falske jærtegn. Dette anstrøg får dog en helt særlig betydning, når man gør sig postillens samlede formål og særpræg klart. Som homiletisk hjælpemiddel ligger Tausens postil nemlig ikke i forlængelse af modelprædikensamlingerne fra middelalderen, og selv i sammenligning med reformationstidens produktion af postiller har den et unikt præg. Efter John M. Frymire's vigtige studie af protestantiske og katolske postiller i Tyskland efter reformationen, The Primacy of the Postils, besidder vi et solidt grundlag for fremtidige komparative studier. Her lader Tausen sig fint indplacere som et dansk modstykke til den fremkomst af lutherske postilforfattere, der indtrådte efter 1535, indledt af Anton Corvins udlægning af kirkeårets evangelietekster. Den øgede produktion af postiller blev affødt af den indsigt, at Luthers Kirkepostil havde fået et ganske upraktisk format. Den var for dyr at anskaffe, og prædikenerne var for lange til at kunne bruges til prædikenkomposition. I forordet til Corvins postil anbefalede Luther selv dens mindre format med korte og klare udlægninger og så nytten af at læse disse udlægninger højt ord-forord for folket (Frymire 2009, 76-78). Der er også noget, der tyder på, at Tausens redaktionelle principper ikke var usædvanlige, da mange postiller var styret af mantraet "udvidet og forbedret" (gemehrt und gebessert), men der er behov for en mere dybdegående sammenligning med potentielle forlæg for at be- eller afkræfte dette (ibid., 177).

Alligevel adskiller Tausens postil sig i kraft af dens nære sammenhæng med det statssanktionerede præsteopdragelsesprogram i kirkeordinansen. Mens Corvin måtte stride med anklager om at skabe dovne præster, fordi man var begyndt at læse hans udlægninger højt fra prædikestolen i stedet for at skrive sine egne prædikener (ibid., 8182), så er Tausens postil specifikt designet til at understøtte en sådan aktivitet, jf. kirkeordinansens bestemmelser om at sognepræsterne på landet havde tilladelse til at læse højt fra danske postiller, som tidligere nævnt. Det giver postillen en unik sammensætning af materiale og en korrigerende og informerende intention, hvor den på én og samme tid skulle udrydde dårlige vaner og falsk lære, erstatte dem med nye, gode vaner og sund lære og forkynde evangeliet. 


\section{Konklusion}

I løbet af reformationen undergik forståelsen af ægteskabet en forandring, men spørgsmålet forbliver, i hvilken grad og af hvilken art forandringen bestod. Nærværende studie over tre prædikener til anden søndag efter helligtrekonger har sporet denne udvikling på tværs af reformationen. Studiet viser, at der er en helt grundlæggende kerne i forståelsen af ægteskabet som godt og gudsskabt, der bevares gennem alle tre prædikener. En kerne, der baseres på en fælles eksegetisk tradition over perikopen: Brylluppet i Kana. Samtidig ses dog et sæt af forskydninger i, hvordan denne kerne appliceres i prædikensamlingens kontekst. I den senmiddelalderlige kontekst, hos både Peter Madsen og Christiern Pedersen, er den grundlæggende præmis, at ægteskabet er en orden af samme art som andre religiøse ordener. Anliggendet bliver, hvordan man skal beskrive forholdet mellem disse forskellige, men til dels ligeværdige, måder at ordne sit liv på, og i dette system tildeles ægteskabets godhed en relativ karakter. Efter reformationen ophæves hos Hans Tausen selve legitimiteten af denne distinktion, hvormed ægteskabets godhed gives en absolut karakter, der fastholdes mod ethvert forsøg på dets relativering.

Denne indsigt skyldes i høj grad, at der med et bevidst metodisk greb lægges et transreformatorisk, kontekstualiserende perspektiv på materialet, hvor prædikenerne læses i lyset af prædikensamlingernes særegne karakter og på tværs af det reformatoriske spænd. Derfor vil jeg - selvom jeg har arbejdet med et lidt andet sæt af parametre støtte op om Frymire’s konklusion, når han siger, at

the use of such sources, it seems to me, should be conducted always with a view towards production, form, distribution, geography, and duration of printing, i.e., it needs to be based on a systematic understanding of these issues before the utterances of individual postillators can be properly interpreted, especially in terms of potential impact (ibid., 438).

På basis af det foregående kan dermed fremføres, at arbejdet med anledning, formål, målgruppe, redaktionelle principper og format er et afgørende, nødvendigt element i det fortsatte systematiske arbejde med prædikensamlingerne og må gå forud for arbejdet med fortolkningen af de enkelte udsagn. 